\title{
RESEARCH
}

Open Access

\section{Transient $\mathrm{O}_{2}$ pulses direct Fe crystallinity and $\mathrm{Fe}(\mathrm{III})$-reducer gene expression within a soil microbiome}

\author{
Jared Lee Wilmoth', Mary Ann Moran² and Aaron Thompson ${ }^{1 *}$ (D)
}

\begin{abstract}
Background: Many environments contain redox transition zones, where transient oxygenation events can modulate anaerobic reactions that influence the cycling of iron (Fe) and carbon (C) on a global scale. In predominantly anoxic soils, this biogeochemical cycling depends on Fe mineral composition and the activity of mixed Fe(III)-reducer populations that may be altered by periodic pulses of molecular oxygen $\left(\mathrm{O}_{2}\right)$.

Methods: We repeatedly exposed anoxic $\left(4 \% \mathrm{H}_{2}: 96 \% \mathrm{~N}_{2}\right)$ suspensions of soil from the Luquillo Critical Zone Observatory to $1.05 \times 10^{2}, 1.05 \times 10^{3}$, and $1.05 \times 10^{4} \mathrm{mmol} \mathrm{O}_{2} \mathrm{~kg}^{-1}$ soil $\mathrm{h}^{-1}$ during pulsed oxygenation treatments. Metatranscriptomic analysis and ${ }^{57} \mathrm{Fe}$ Mössbauer spectroscopy were used to investigate changes in Fe(III)-reducer gene expression and Fe(III) crystallinity, respectively.

Results: Slow oxygenation resulted in soil Fe-(oxyhydr)oxides of higher crystallinity ( $38.1 \pm 1.1 \%$ of total Fe) compared to fast oxygenation $(30.6 \pm 1.5 \%, P<0.001)$. Transcripts binning to the genomes of Fe(III)-reducers Anaeromyxobacter, Geobacter, and Pelosinus indicated significant differences in extracellular electron transport (e.g., multiheme cytochrome c, multicopper oxidase, and type-IV pilin gene expression), adhesion/contact (e.g., S-layer, adhesin, and flagellin gene expression), and selective microbial competition (e.g., bacteriocin gene expression) between the slow and fast oxygenation treatments during microbial Fe(III) reduction. These data also suggest that diverse Fe(III)-reducer functions, including cytochrome-dependent extracellular electron transport, are associated with type-III fibronectin domains. Additionally, the metatranscriptomic data indicate that Methanobacterium was significantly more active in the reduction of $\mathrm{CO}_{2}$ to $\mathrm{CH}_{4}$ and in the expression of class(III) signal peptide/type-IV pilin genes following repeated fast oxygenation compared to slow oxygenation.

Conclusions: This study demonstrates that specific Fe(III)-reduction mechanisms in mixed Fe(III)-reducer populations are uniquely sensitive to the rate of $\mathrm{O}_{2}$ influx, likely mediated by shifts in soil Fe(III)-(oxyhydr)oxide crystallinity. Overall, we provide evidence that transient oxygenation events play an important role in directing anaerobic pathways within soil microbiomes, which is expected to alter Fe and C cycling in redox-dynamic environments.
\end{abstract}

Keywords: Soil microbiome, Redox cycling, Microbial Fe(III) reduction, C cycling, Metatranscriptomics, Mössbauer spectroscopy

\footnotetext{
* Correspondence: AaronT@uga.edu

'Department of Crop and Soil Sciences, University of Georgia, Athens 30602,

GA, USA

Full list of author information is available at the end of the article
}

(c) The Author(s). 2018 Open Access This article is distributed under the terms of the Creative Commons Attribution 4.0 International License (http://creativecommons.org/licenses/by/4.0/), which permits unrestricted use, distribution, and reproduction in any medium, provided you give appropriate credit to the original author(s) and the source, provide a link to the Creative Commons license, and indicate if changes were made. The Creative Commons Public Domain Dedication waiver (http://creativecommons.org/publicdomain/zero/1.0/) applies to the data made available in this article, unless otherwise stated. 


\section{Background}

Soils in diverse terrestrial ecosystems (e.g., humid forests, wetlands, and irrigated agricultural lands) often undergo fluctuations in $\mathrm{O}_{2}$ during periodic wetting and drying events, and experience depletion of $\mathrm{O}_{2}$ during heterotrophic microbial respiration when the bulk soil or microsites within soil aggregates become saturated with water [1-4]. In soils, Fe(III) is typically the most abundant terminal electron acceptor for microbial respiration after $\mathrm{O}_{2}$. The soil microbiome is therefore strongly influenced by Fe during periods of low $\mathrm{O}_{2}$ because the microbial reduction of $\mathrm{Fe}(\mathrm{III})$ to $\mathrm{Fe}(\mathrm{II})$ can dominate important biogeochemical reactions [5-8]. Much of the Fe in soil exists as Fe(III)-(oxyhydr)oxides [9], but also as substituted $\mathrm{Fe}(\mathrm{III}) / \mathrm{Fe}(\mathrm{II})$ within clay minerals and as organo-Fe complexes [10-12]. Under both low and $\mathrm{O}_{2}$-rich conditions, Fe(III) phases are major sorbents for nutrients and organic matter and influence the flocculation and dispersion of soil colloids $[13,14]$. The most disordered, lowest crystallinity $\mathrm{Fe}(\mathrm{III}$ )-(oxyhydr)oxides (known as short-range-ordered (SRO) Fe phases) are widely understood to govern the abundance of organic C (OC) (along with SRO Al phases) in soils and sediments [15], especially in humid climatic regimes [16, 17]. During low- $\mathrm{O}_{2}$ conditions, microbial respiration on SRO Fe(III) phases typically results in their mineral dissolution and the loss of their OC- and nutrient-binding capability [18-20].

Pulsing of $\mathrm{O}_{2}$ or a return to $\mathrm{O}_{2}$-rich conditions following microbial $\mathrm{Fe}(\mathrm{III})$ reduction to $\mathrm{Fe}(\mathrm{II})$ promotes the re-precipitation of $\mathrm{SRO} \mathrm{Fe}(\mathrm{III})$ phases, thereby renewing $\mathrm{Fe}(\mathrm{III})$ as an available electron acceptor for microbial respiration should low- $\mathrm{O}_{2}$ conditions return [5]. Recently precipitated $\mathrm{Fe}(\mathrm{III})$ mineral phases are often less crystalline and thus more reactive toward nutrient/carbon sorption and microbial reduction $[9$, 11, 21, 22]. Consequently, redox-driven transformations of Fe-(oxyhydr)oxides can have a profound effect on the mineralization of $\mathrm{OC}$ in soil microbiomes and by extension alter ecosystem-level processes such as $\mathrm{C}$ turnover rates, greenhouse gas emissions, and plant nutrient availability [23-31]. However, the underlying mechanisms of how different microbial Fe(III) reducers respond to the geochemical Fe species formed in redox-fluctuating systems remain poorly understood [5, 32-34].

The particle size and reactivity of $\mathrm{Fe}(\mathrm{III})$ minerals are influenced by the degree of disorder in the crystal structure, such that more disordered phases are typically smaller and have higher reactivity per mass, and are thus more energetically favorable as electron acceptors during microbial Fe(III) reduction [19-21, 35, 36]. Extracellular reduction of solid-phase Fe-(oxyhydr)oxides by $\mathrm{Fe}(\mathrm{III})$-reducing bacteria (e.g., Geobacter and
Shewanella) is facilitated by multiheme cytochromes, electrically conductive pili, flagella, biofilms, and soluble electron-shuttling compounds that can be regulated by differences in Fe crystallinity and reactivity [32, 33, 37-44]. Compared to pure culture experiments, rapid oxygenation of anoxic soil suspensions containing native Fe minerals and mixed Fe(III)-reducer populations has been shown to regulate microbial Fe(III) reduction rates during subsequent anoxic conditions, likely through the production of more available/reactive $\mathrm{Fe}(\mathrm{III})$ phases relative to bulk soil Fe [6, 7]. Consequently, the transcriptomic activity of mixed Fe(III)-reducer populations in the soil microbiome should reflect important changes in Fe and C cycling [28, 33, 45, 46].

Unlike synthetic $\mathrm{Fe}(\mathrm{III})$ phases often used in relevant gene expression studies [32, 33, 39, 43], Fe minerals found in soil are often highly substituted with foreign ions or organic compounds and have disordered crystal structure [47-51]. During the laboratory synthesis of $\mathrm{Fe}(\mathrm{III})$-(oxyhydr)oxides, slower or faster rates of Fe(II) oxidation by $\mathrm{O}_{2}$ lead to the formation of either more crystalline or less crystalline Fe(III) phases, respectively [52-55]. Additionally, many researchers have found that when $\mathrm{Fe}(\mathrm{III})$ phases are exposed to aqueous or sorbed Fe(II), which occurs during microbial Fe(III) reduction, mineral ripening (Ostwald) increases along with changes in $\mathrm{Fe}(\mathrm{III})$ crystallinity $[36,56]$. The crystallinity of soil $\mathrm{Fe}(\mathrm{III})$ minerals can increase [27, 57, $58]$, decrease $[22,59]$, or remain unchanged/undetected [34] in response to redox fluctuations; however, the mechanisms governing these processes are still unclear $[6,57,60]$.

To examine the effect of transient oxygenation on $\mathrm{Fe}(\mathrm{III})$-reducer gene expression and Fe mineral transformations in soil, we repeatedly exposed the headspace of anoxic soil suspensions to pulses of $\mathrm{O}_{2}$ at different influx rates. We chose soil from the Bisley Watershed of the Luquillo Critical Zone Observatory (LCZO), Puerto Rico, because it has a well-documented history of redox fluctuations in the field and is well characterized in terms of mineral and microbial composition [2, 6, 18,61]. We tested the hypothesis that slow oxygenation rates lead to the buildup of more crystalline $\mathrm{Fe}(\mathrm{III})$ phases and characterized how $\mathrm{Fe}(\mathrm{III})$-reducer gene expression is affected under different treatment conditions. Variable temperature ${ }^{57} \mathrm{Fe}$ Mössbauer spectroscopy was used to track changes in Fe mineral composition while metatranscriptomic analysis was used to measure the presence and relative abundance of mRNA transcripts binning to $\mathrm{Fe}(\mathrm{III})$-reducer genomes. Our study demonstrates that combining ${ }^{57} \mathrm{Fe}$ Mössbauer spectroscopy and a metatranscriptomic analysis of $\mathrm{Fe}(\mathrm{III})$-reducing taxa provides a novel view of the mineral-microbe interface in redox-fluctuating systems. 


\section{Methods}

\section{Sample collection}

Soil was collected from the Bisley Watershed (LCZO), Luquillo Experimental Forest, Puerto Rico. Soil characteristics, geographic coordinates, and site-specific details including annual precipitation have been reported elsewhere $[2,6,18,62]$. Sample processing details are given in Additional file 1: Section 1.

\section{$\mathrm{O}_{2}$ pulse methodology}

We used $120 \mathrm{ml}$ dark amber serum bottles (Wheaton, Millville, NJ, USA) as microcosms during a 31-day anoxic incubation with three 7 -h pulses of $\mathrm{O}_{2}$ at different delivery rates initiated every 7 days. Soils ( 2 g, air dried) were placed in serum bottles and moved into an anoxic chamber (Coy Labs, Grass Lake, MI, USA; 4\% $\mathrm{H}_{2}: 96 \%$ $\mathrm{N}_{2}$ ), mixed with $20 \mathrm{ml}$ of anoxic $25 \mathrm{mM}$ (2-(N-morpholino)ethanesulfonic acid (MES) $+\mathrm{KCl}$ ) buffer $(\mathrm{pH} 6)$, sealed with gray butyl stoppers and aluminum crimp caps, and then mounted on a rotary shaker in the anoxic chamber. To induce oxygenation following 7-day anoxic conditions, $\left[\mathrm{O}_{2}\right]_{\mathrm{atm}}\left(21 \% \mathrm{O}_{2}\right.$ in air) was added to triplicate microcosms over an initial $7 \mathrm{~h}$ period (i.e., at the onset of oxygenation), each hour, as $2.1 \times 10^{-4} \mathrm{~mol} \mathrm{~h}^{-1}$ (slow treatment), $10^{-3} \mathrm{~mol} \mathrm{~h}^{-1}$ (medium treatment), or $10^{-2} \mathrm{~mol} \mathrm{~h}^{-1}$ (fast treatment). Following $7 \mathrm{~h}$ of oxygenation, an additional $17 \mathrm{~h}$ was allowed to pass before again exposing the microcosms to an anoxic headspace in the chamber (i.e., total oxic time $=24 \mathrm{~h}$ ). A single addition to the slow, medium, and fast oxygenation treatments introduced $1.05 \times 10^{2}, 1.05 \times 10^{3}$, and $1.05 \times 10^{4} \mathrm{mmol} \mathrm{O}_{2} \mathrm{~kg}^{-1}$ soil, respectively, and would theoretically be able to oxidize $4.2 \times 10^{2}, 1.05 \times 10^{3}$, and $1.05 \times 10^{4} \mathrm{mmol} \mathrm{Fe}(\mathrm{II}) \mathrm{kg}^{-1}$ soil at $\mathrm{pH} 6$, respectively, if $\mathrm{Fe}(\mathrm{II})$ was the only species oxidized [52]. This cycle of 7 days of anoxic conditions and a 7-h pulse of $\mathrm{O}_{2}$ was repeated three times and then followed finally by 7 days of anoxic conditions to complete the 31-day incubation (see Additional file 1: Section 1 for more details).

\section{Incubation sampling scheme and Fe chemical analyses}

Samples $(1 \mathrm{ml})$ were collected for Fe(II) chemical analysis using sterile 10-ml plastic syringes fitted with wide bore needles (16 ga; $1.2 \mathrm{~mm}$ id; sterile stainless steel) at 0 day, at the end of each 7-day anoxic period, and after 1,3 , and $24 \mathrm{~h}$ during each oxic period unless otherwise indicated (see Additional file 1: Section 1). Aliquots were centrifuged at 21,000 rcf for $15 \mathrm{~min}$ and returned to the anoxic chamber for collection of the aqueous phase, and then, the remaining soil pellet was extracted with $0.5 \mathrm{M} \mathrm{HCl}$ for $2 \mathrm{~h}$ in the dark and centrifuged at $21,000 \mathrm{rcf}$ for $15 \mathrm{~min}$ prior to collection of the acid supernatant. Measurement of aqueous and acid extractable $\mathrm{Fe}(\mathrm{II})$ was carried out using a modified ferrozine assay [57], and $\mathrm{Fe}_{\text {Total }}$ in the initial soil was determined using lithium-metaborate fusion (sub-contracted to Australian Laboratory Services (ALS) Minerals, Reno, NV, USA).

\section{Variable temperature ${ }^{57} \mathrm{Fe}$ Mössbauer spectroscopy}

Samples collected under oxic conditions for Mössbauer spectroscopy at 24 days during the incubation were centrifuged as described above for Fe chemical analyses, and the supernatants were subsequently removed in the anoxic chamber. Soil pellets remaining in the micro-centrifuge tubes were sealed under anoxic headspace and stored at $80{ }^{\circ} \mathrm{C}$ until further analysis. Frozen samples were transferred to the anoxic chamber and prepared as sealed mounts for Mössbauer spectroscopy measurements. For each treatment, replicate soil gels $(n=3)$ were mixed (i.e., pooled) (180 mg per total equivalent dry mass mount) within the cavity of a thin nylon ring and sealed between two layers of Kapton tape. The mounts were then frozen and introduced to a He-cooled Mössbauer spectrometer at low temperature $(<100 \mathrm{~K})$ to prevent changes in mineralogy.

Absorption spectra of the initial air-dried soil and sampled incubation soils were collected in transmission mode with a variable temperature He-cooled cryostat (Janis Research Co.) and a 1024 channel detector. A ${ }^{57} \mathrm{Co}$ source $(\sim 50 \mathrm{mCi})$ embedded in a $\mathrm{Rh}$ matrix was used at room temperature. Velocity (i.e., gamma-ray energy) was calibrated using $\alpha$-Fe foil at $295 \mathrm{~K}$, and all center shift (CS) and peak positions were reported with respect to this standard. The transducer was operated in constant acceleration mode, and the spectra were folded to 512 channels to achieve a flat background. Mössbauer spectral fitting was performed using Recoil ${ }^{\mathrm{TM}}$ software (ISA Inc.) with the Voigt-based fitting (VBF) method. The Lorentzian linewidth (HWHM) parameter was held at $0.1425 \mathrm{~mm} \mathrm{~s}^{-1}$, corresponding to the measured linewidth using $\alpha$-Fe foil at $295 \mathrm{~K}$ on our instrument. Mössbauer spectroscopy methods and associated references are given in detail in Additional file 1: Section 2.

\section{RNA isolation, sequencing, and analysis}

Methods for RNA extraction and sequencing followed Gifford et al. [63] and Tveit et al. [64]. Soil suspensions collected for RNA sequencing at 31 days were transferred inside the anoxic chamber and then immediately frozen in liquid $\mathrm{N}_{2}$ and subsequently stored at $-80{ }^{\circ} \mathrm{C}$ until further analysis. Samples were prepared for RNA extraction by transferring frozen fragments to bead tubes (Mo Bio, Carlsbad, CA, USA) on dry ice. A stream of $\mathrm{N}_{2}$ was used to flush the headspace of each bead tube and then capped to prevent any dramatic redox changes in the steps that followed. To begin extraction (1 g per dry soil mass equivalent extraction), the sealed $\mathrm{N}_{2}$-flushed tubes were 
quickly moved between ice and brief vortexing to initiate thawing. The samples were then immediately placed in a $0{ }^{\circ} \mathrm{C}$ centrifuge and spun at $4,000 \times \operatorname{rcf}$ for $7 \mathrm{~min}$. Removal of the separated aqueous phase after centrifugation marked the immediate transition to step 1 of total RNA extraction as detailed in the RNA PowerSoil ${ }^{\circ}$ Total RNA Isolation Kit (Mo Bio) user protocol, and total RNA was then extracted from soils following the manufacturer's instructions. All mass transfers that occurred during extraction were recorded during the procedure to calculate RNA yields on a dry soil basis. Initial RNA yields and purity were measured on a NanoDrop spectrophotometer.

The Bacteria Ribo-Zero Magnetic Kit (Epicenter-Illumina, Madison, WI, USA) was used to remove ribosomal RNA (rRNA). Linear amplification of the resuspended rRNA-depleted samples was performed using the MessageAmp II-Bacteria Kit (Ambion', Thermo Fisher Scientific, Waltham, MA, USA). Fragment size analysis and integrity of the mRNA-amplified samples were checked on a TapeStation 2200 (Agilent Technologies, Santa Clara, CA, USA). Sequence cDNA libraries were constructed, following quality control assessment on a BioAnalyzer 2100 (Agilent), using the KAPA Stranded RNA-Seq kit (Kapa Biosystems, Wilmington, MA, USA) with TruSeq adapters (Illumina, San Diego, CA, USA). Libraries were pooled and sequenced on four lanes using the NextSeq platform (Illumina) to generate $150 \mathrm{nt}$ paired-end sequences. Library construction, process quality control, and sequencing were performed at the Georgia Genomics and Bioinformatics Core, Athens, GA, USA.

Sequence quality was evaluated using the program FastQC. PEAR was used to merge paired-end sequences, and Prinseq was used to trim poly-A/T tails $\geq 15 \mathrm{nt}$ added in the RNA amplification procedure. RiboPicker was used to remove rRNA sequences $(16 \mathrm{~S}, 23 \mathrm{~S}, 18 \mathrm{~S}, 28 \mathrm{~S}, 5 \mathrm{~S}$, and $5.8 \mathrm{~S}$ units) using a standalone non-redundant rRNA database (rrnadb) which included the most current versions of SILVA, Ribosomal Database Project RDP-II, GreenGenes, NCBI archeal/bacterial complete genomes rRNA and Rfam databases. Alignments of the remaining sequences were performed with DIAMOND using sensitive-BLASTX searches (bit score $\geq 40, E$ value $\leq 10^{-3}$ ) against the NCBI RefSeq protein database. MEGAN6 software was used to bin putative mRNA sequences taxonomically (RefSeq) and functionally (Interpro) and was also used to perform principal coordinates analysis (PCoA). Distance matrices for PCoA analysis were calculated using Bray-Curtis distances in MEGAN6. Values for the number of sequences surviving each step of processing are given in Additional file 2: Table S1. Significant differences in relative gene expression between treatments were measured using DESeq2. Statistical values are those reported by DESeq2 using an adjusted $P$ cutoff of 0.1 . A complete RefSeq accession-to-annotation key is given in Additional file 3: Table S2. The primary data handling and analyses were performed on a Linux cluster at the Georgia Advanced Computing Resource Center, Athens, GA, USA.

All original sequence data are under BioProject PRJNA381321 in the NCBI SRA database (https:// www.ncbi.nlm.nih.gov/Traces/study/?acc=SRP103306). The corresponding sample accessions are listed in Additional file 2: Table S1. A full account of the above RNA sampling and analysis pipeline, including the associated references, is included in Additional file 1: Section 1.

\section{Results}

\section{$\mathrm{Fe}$ (II) chemical analysis}

Anoxic Fe(II) concentrations were similar at the end of the experiment for all treatments in both the aqueous and solid phases (Fig. 1a) and increased as the incubation progressed, consistent with prior work which used air-dried soils from this site [6, 7]. HCl-extractable $\mathrm{Fe}(\mathrm{II})$ approached $300 \mathrm{mmol} \mathrm{\textrm {kg } ^ { - 1 }}$ by 31 days in all treatments, whereas $\mathrm{Fe}(\mathrm{II})_{\mathrm{aq}}$ concentrations never in-

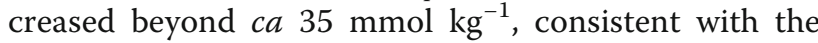
$\mathrm{Fe}(\mathrm{II})$ sorption isotherm for this soil (Additional file 1: Figure S13). Following oxygenation at both 16 and 24 days (i.e., the end of redox cycles two and three), aqueous and $\mathrm{HCl}$-extractable $\mathrm{Fe}(\mathrm{II})$ remained higher in the slow treatment (Fig. 1a). By the end of the incubation, $\mathrm{Fe}(\mathrm{II})$ concentrations in all treatments reached $29 \%$ of $\mathrm{Fe}_{\text {Total }}\left(\mathrm{Fe}_{\mathrm{Total}}=1162.5 \pm 17.5 \mathrm{mmol} \mathrm{kg}{ }^{-1}\right.$ soil $)$. There was no significant difference in $\mathrm{Fe}(\mathrm{III})$ reduction rates $(\mathrm{aq}+$ solid $\mathrm{Fe}(\mathrm{II}))$ between treatments over the last 3 days of the incubation.

\section{Mössbauer analysis of soil Fe phase crystallinity}

Soils at the initiation of the experiment, those collected at 24 days following fast oxygenation, and those at 24 days following slow oxygenation all had prominent sextet-components in the 77 Kelvin (K) Mössbauer spectra that accounted for $25 \pm 1.2,30.6 \pm 1.5$, and $38.1 \pm$ $1.1 \% \mathrm{Fe}_{\text {Total }}$, respectively, which indicates increasing $\mathrm{Fe}$ (III)-(oxyhydr)oxide crystallinity (initial $<$ fast treatment $<$ slow treatment) (Fig. 1b). There was a significantly larger sextet-component contribution in the slow oxygenation treatment compared to the fast oxygenation treatment ( $T$ test; $P<0.001$ ), and in the fast oxygenation treatment compared to the initial soil $(P<0.01)$. In all cases, the sextets had spectral parameters most closely associated with nano-goethite $(\alpha-\mathrm{FeOOH})$ (see Additional file 1: Section 2 and Additional files 4, 5, 6 , and 7). For the initial soil and treatments, we found that at least $50 \%$ of $\mathrm{Fe}(\mathrm{II})$ displayed weak magnetic order at $4.5 \mathrm{~K}$. We did not include the medium oxygenation treatment in our final Mössbauer or 

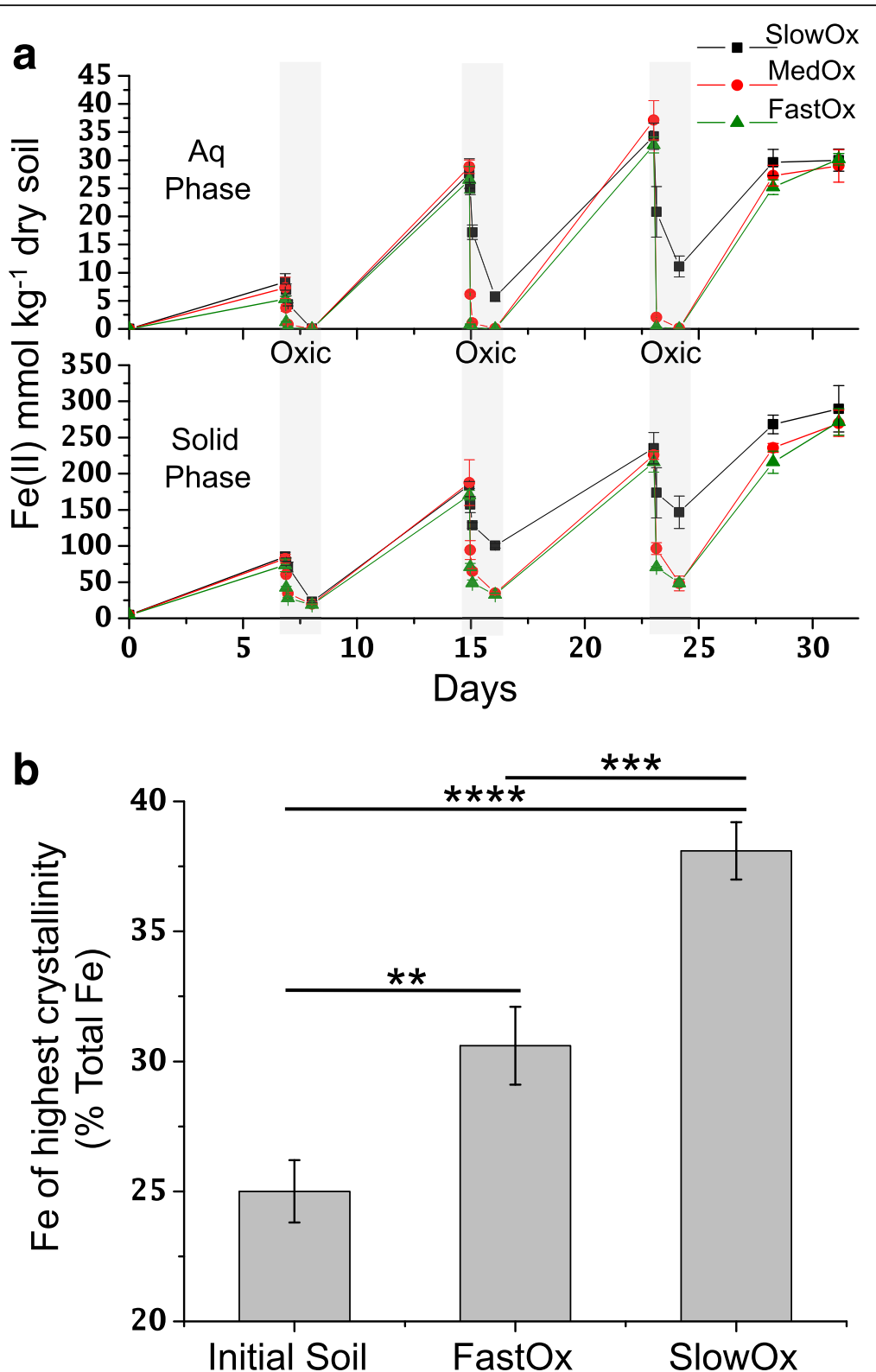

Fig. $1 \mathrm{Fe}(\mathrm{II})$ concentrations and Fe(III) solid phase crystallinity under different oxygenation treatments. a Amount of Fe(II) extracted from the aqueous and solid phases when $\left[\mathrm{O}_{2}\right]_{\text {atm }}\left(21 \% \mathrm{O}_{2}\right.$ in air) was supplied at $2.1 \times 10^{-4}$ (SlowOx), $2.1 \times 10^{-3}$ (MedOx), or $2.1 \times 10^{-2}$ (FastOx) mol h ${ }^{-1}$. Data points are means ( \pm s.d.)

$(n=3)$. Light gray vertical bars denote 24-h periods under oxic conditions, see Additional file 1: Figure S1 for expanded view of oxic intervals. b Mössbauer results showing differences in Fe crystallinity between oxygenation treatments. T test significance: ${ }^{* *} P<0.01,{ }^{* * *} P<0.001,{ }^{* * * *} P<0.0001$. Triplicate samples were pooled prior to Mössbauer analysis. The error bars represent standard deviations in the signal modeling (see Additional file 1: Section 2 for details)

metatranscriptomic analyses (see also Additional file 1: Section 1); the following sections report only the metatranscriptomic data from the fast and slow oxygenation treatments.

\section{Microbial community attributes}

Microbial taxa were identified based on transcripts recruiting to reference genomes at both the genus and species level following normalization of total transcript counts per sample in MEGAN6. The number of active species detected in the fast oxygenation treatment $(1020 \pm 80)$ was significantly greater than in the slow oxygenation treatment $(870 \pm 40)(T$ test; $P<0.05$; Additional file 1: Figure S2). The PCoA results based on taxonomic and functional assignment of transcripts show that replicate samples exposed to the 

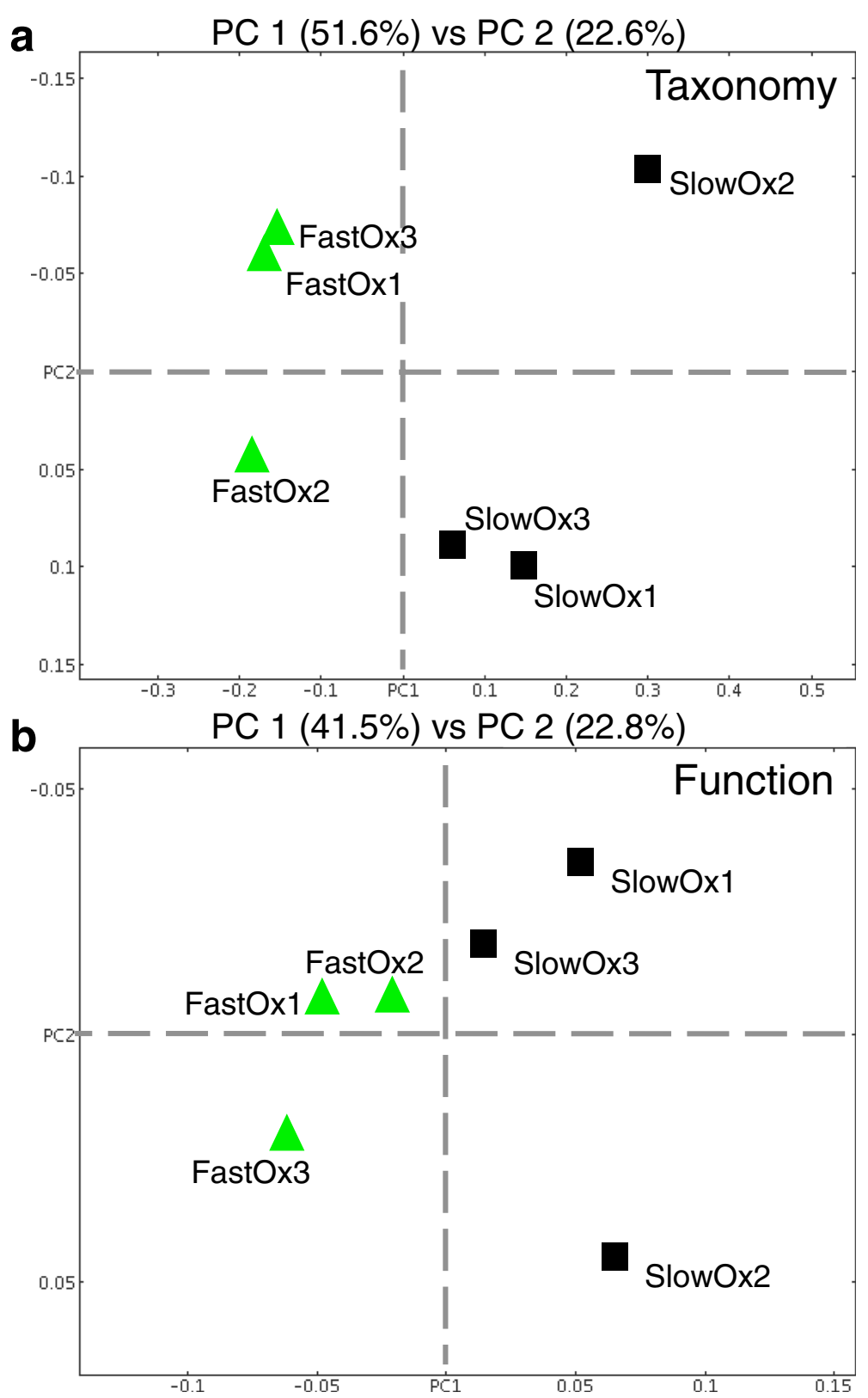

Fig. 2 Principal coordinates analysis (PCOA) for oxygenation treatments using Bray-Curtis distances. a Genus assignments in MEGAN6 using NCBI taxonomy classifications. b Functional assignments in MEGAN6 using Interpro classifications

same oxygenation treatment tended to group together (Fig. 2).

\section{Important $\mathrm{Fe}(\mathrm{III})$ reducers}

Overall, $543 \pm 59$ and $638 \pm 54$ genera were detected in the slow and fast oxygenation treatments, respectively. Rankings of the top 50 genera by relative contribution to the metatranscriptome indicate that bacteria belonging to the genera Anaeromyxobacter, Geobacter, and Pelosinus were major Fe(III) reducers in both treatments (Additional file 1: Figure S3). The relatively large metatranscriptomic contribution of these three genera is consistent with the geochemical profile of the humid forest soil used in our experiment, which is replete with nano-phase Fe-(oxyhydr)oxides. Specifically, Anaeromyxobacter and Geobacter are known to express characteristic genes during extracellular electron transfer to Fe(III), such as multiheme cytochrome $c$ genes, which is expected to depend on Fe mineral crystallinity/reactivity in soils [32, 33, 65]. Recent investigations have identified Pelosinus as a predominant Fe(III)-reducing genus in diverse anaerobic and heavy-metal rich environments, where 
specific extracellular matrix components of Pelosinus (e.g., S-layer complexes) mediate reactions with heavy metals [66-69]. Other minor and less well-known microbial contributors to extracellular Fe(III) reduction were likely present, but our metatranscriptomic focus on transcripts recruiting to Anaeromyxobacter, Geobacter, and Pelosinus genomes provided a more solid biological basis for our analysis of characteristic $\mathrm{Fe}(\mathrm{III})$-reducer activity within the soil microbiome.

\section{Differentially expressed and other essential genes for $\mathrm{Fe}$ (III) reduction following soil oxygenation at different rates}

We measured significantly higher relative expression for an omcA/mtrC (outer membrane) multiheme cytochrome $c$ gene, a type-IV pilin pilO-homology gene, and flagellin genes in the fast oxygenation treatment than in the slow treatment, consistent with changes in extracellular Fe(III) reduction (Fig. 3). Membrane adhesin and S-layer genes, which we believe to be involved in the reduction of $\mathrm{Fe}(\mathrm{III})$, and a vault protein inter-alpha-trypsin $(V I T)$ gene also showed significantly higher relative expression in the fast treatment. VIT proteins form nano-cage structures that are important for transport and extracellular matrix stabilization (e.g., biofilms) [70], which are expected to be essential processes during microbial $\mathrm{Fe}(\mathrm{III})$ reduction in soil microbiomes. A gene containing domains for both heavy metal transport and cytochrome $c$ biogenesis and a $4 \mathrm{Fe}-4 \mathrm{~S}$ oxidoreductase gene also showed significantly higher relative expression in the fast treatment than in the slow treatment that is consistent with Fe(III) reduction. Also showing significantly higher expression in the fast treatment were fibronectin and sialidase genes that in the closest reference genomes contain cellulosome-associated type-I dockerin domains, suggesting involvement in the degradation of cellulose. This indicates that cellulose might serve as an important organic $\mathrm{C}$ (OC) electron donor for $\mathrm{Fe}(\mathrm{III})$ reduction in soils. There were fewer genes that showed significantly higher relative expression in the slow oxygenation treatment compared to the fast oxygenation treatment (Fig. 4). These included a multicopper oxidase gene, a multiheme cytochrome $c /$ fibronectin type-III domain gene, and a heavy metal translocase gene that are all consistent with changes in extracellular Fe(III) reduction.

Other expressed genes that are informative about $\mathrm{Fe}$ cycling, but that were not significantly different in relative expression between the fast and slow treatment, match multicopper oxidase, fibronectin type-III domain, cytochrome $c$, multiheme cytochrome $c$, and $4 \mathrm{Fe}-4 \mathrm{~S}$ genes of Geobacter, including genes likely involved in $\mathrm{C}$ and $\mathrm{H}_{2}$ metabolism (i.e., encoding dehydrogenase and hydrogenase enzymes) (Fig. 5). Similar genes required

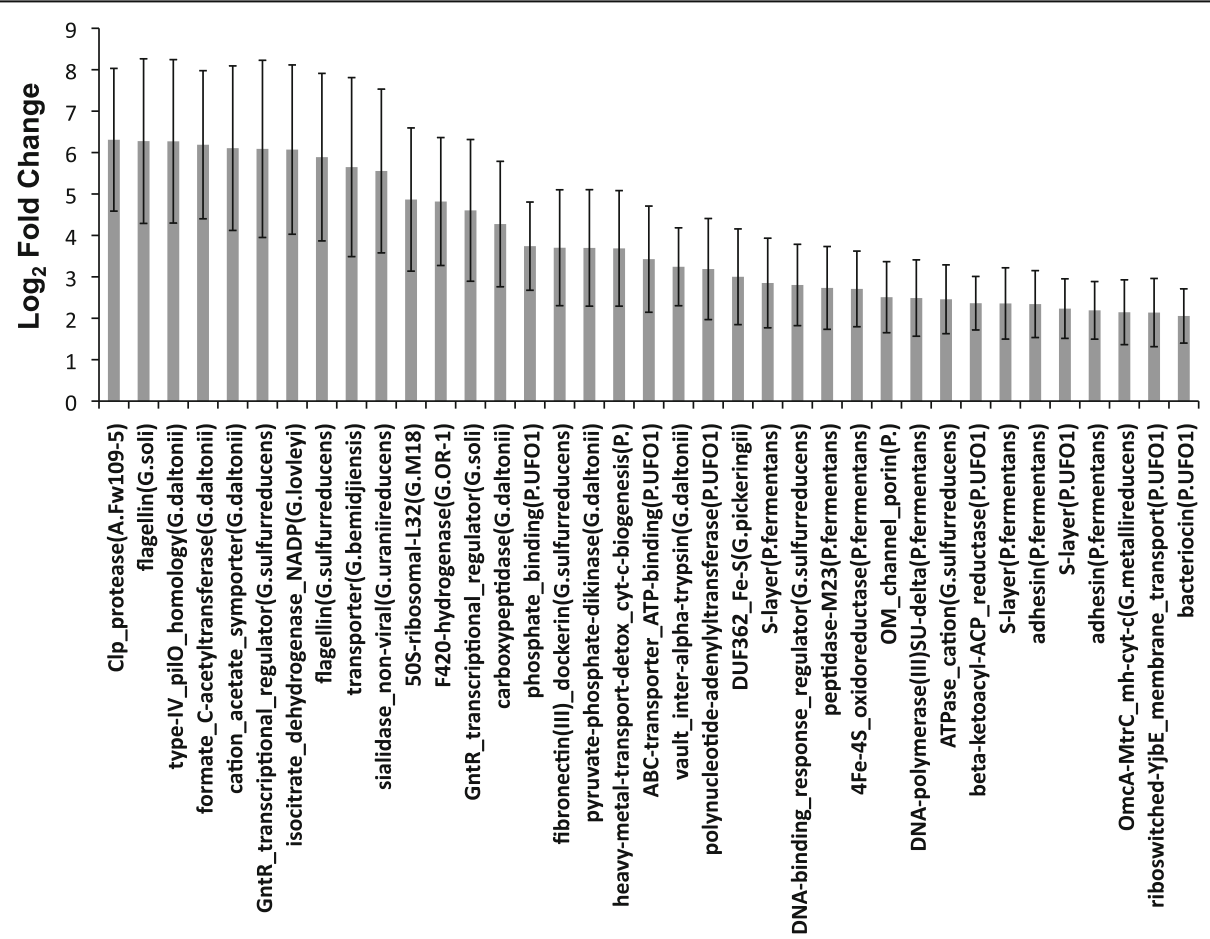

Fig. 3 All differentially expressed genes of Anaeromyxobacter, Geobacter, and Pelosinus detected at significantly higher levels in the fast oxygenation treatment (DESeq; $P<0.01)$. Bars indicate means ( \pm s.e.) $(n=3)$. Taxonomic annotation is shown in parentheses denoted by A. (Anaeromyxobacter), G. (Geobacter), or P. (Pelosinus). A complete RefSeq accession-to-annotation key is given in Additional file 3: Table S2 


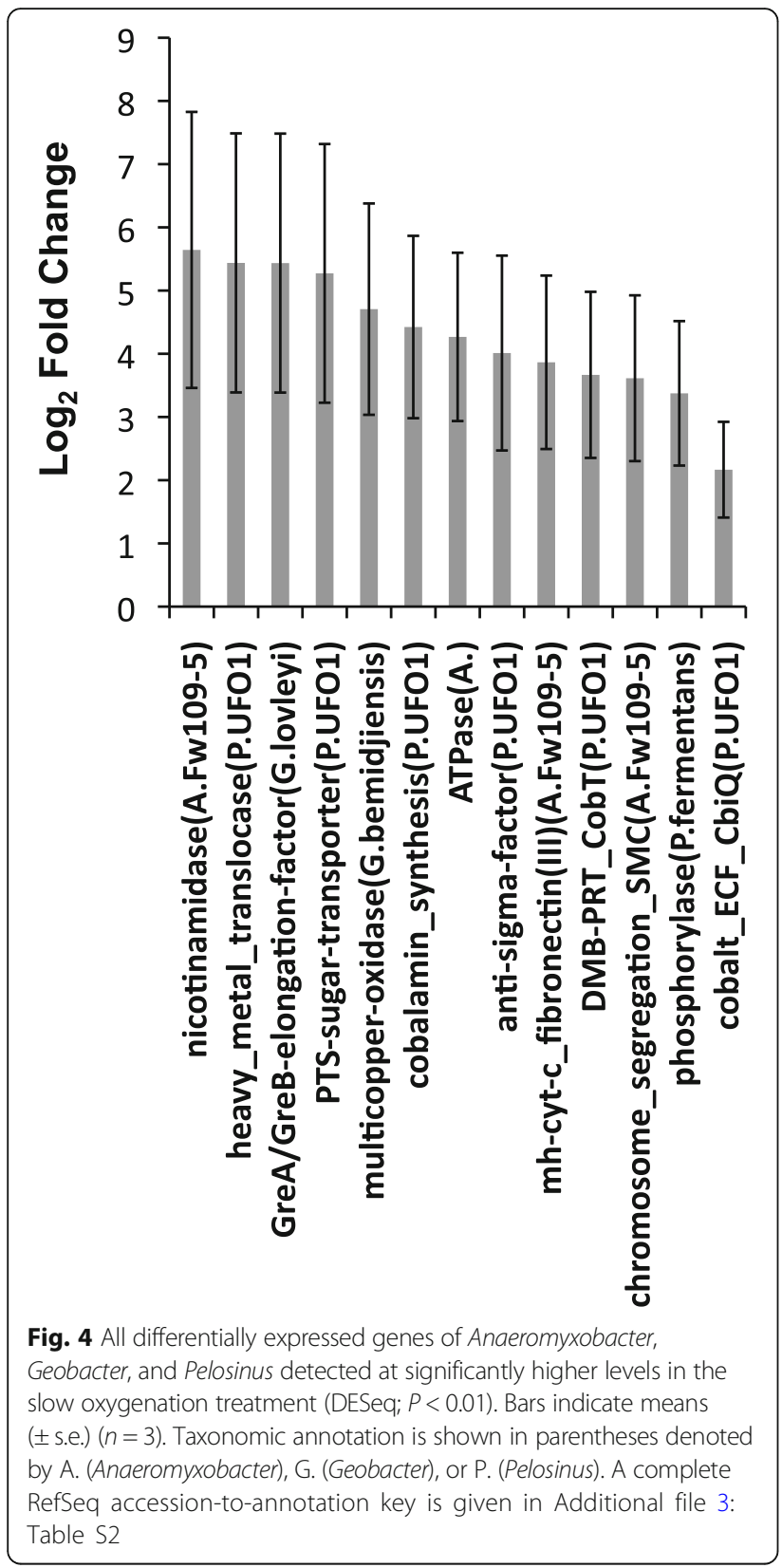

for anaerobic $\mathrm{Fe}(\mathrm{III})$ reduction were previously reported to be more highly expressed in uranium (U)-contaminated subsurface sediments compared to defined growth media [46]. Fibronectin type-III domain genes matching to Geobacter that also encode dockerin, cupredoxin, and laccase enzymes were highly expressed in our study. Importantly, these enzymes may be used for insoluble $\mathrm{Fe}(\mathrm{III})$ reduction [42], perhaps owing to the redox activity of multicopper constituents and/or the ability to oxidize organic compounds during electron transfer from soil OC to $\mathrm{Fe}(\mathrm{III})$. A highly expressed chitobiase gene matching to the G. pickeringii genome may suggest involvement in chitin degradation and consequently

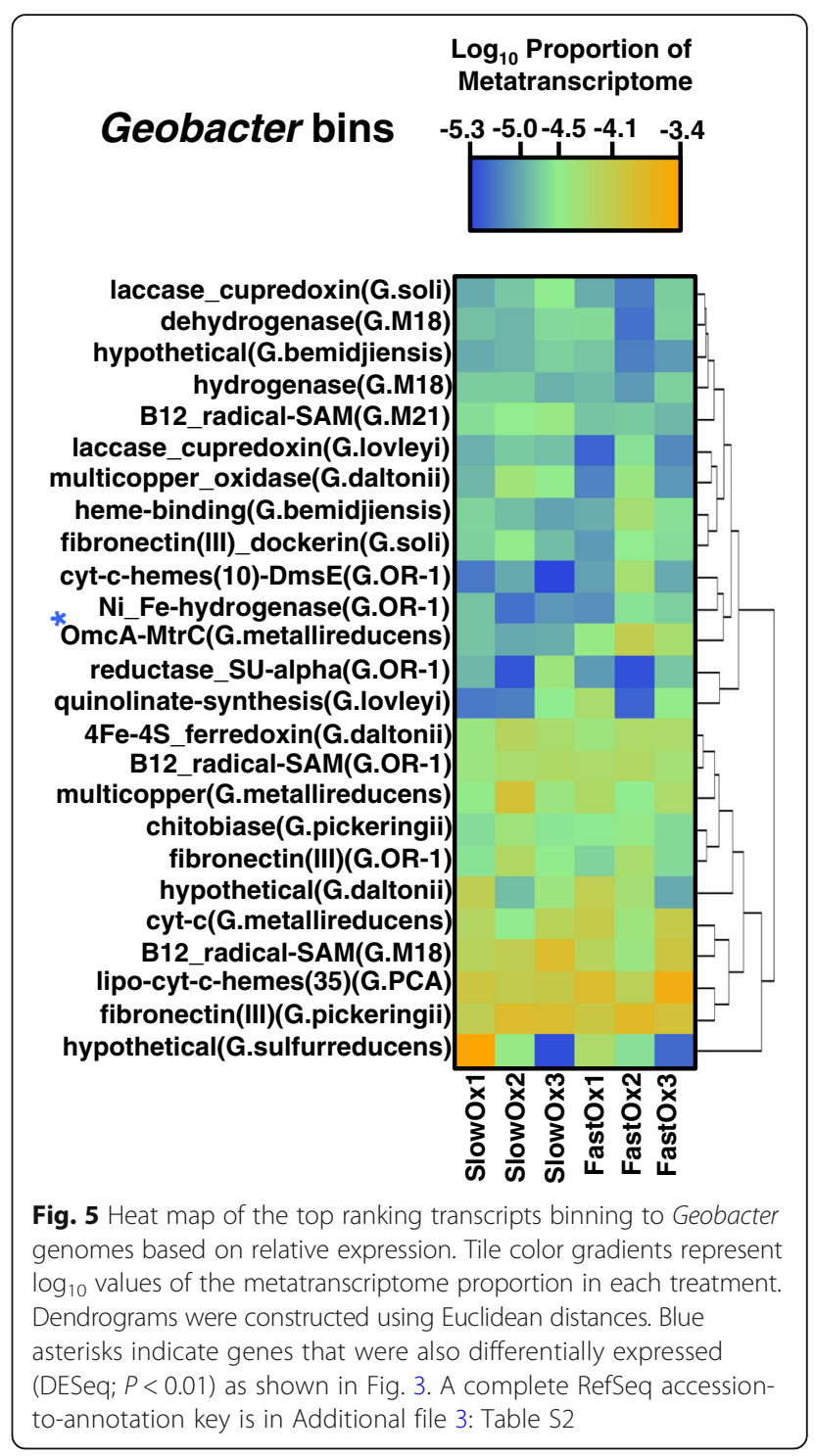

electron donation from this type of recalcitrant $\mathrm{OC}$ during Fe(III) reduction in the soil. The transcripts recruiting to Pelosinus genomes with high relative expression in both treatments included different S-layer encoding genes (Fig. 6), which we expect to play a vital role in the assembly and reduction of $\mathrm{Fe}(\mathrm{III})$ in the soil. However, the expression of certain S-layer genes is likely more characteristic for changes in $\mathrm{Fe}(\mathrm{III})$-(oxyhydr)oxide crystal order as indicated in Fig. 3. The three top-most expressed genes of Pelosinus (Fig. 6) in both treatments are related to pgaA (poly-beta-1,6 $\mathrm{N}$-acetyl-D-glucosamine export porin) of Cupriavidus basilensis. The pgaA gene is necessary for biofilm formation in Gram-negative bacteria, and based on our findings, could be involved in the cellular contact/ reduction of reactive Fe(III)-(oxyhydr)oxides by Pelosinus in the soil. 


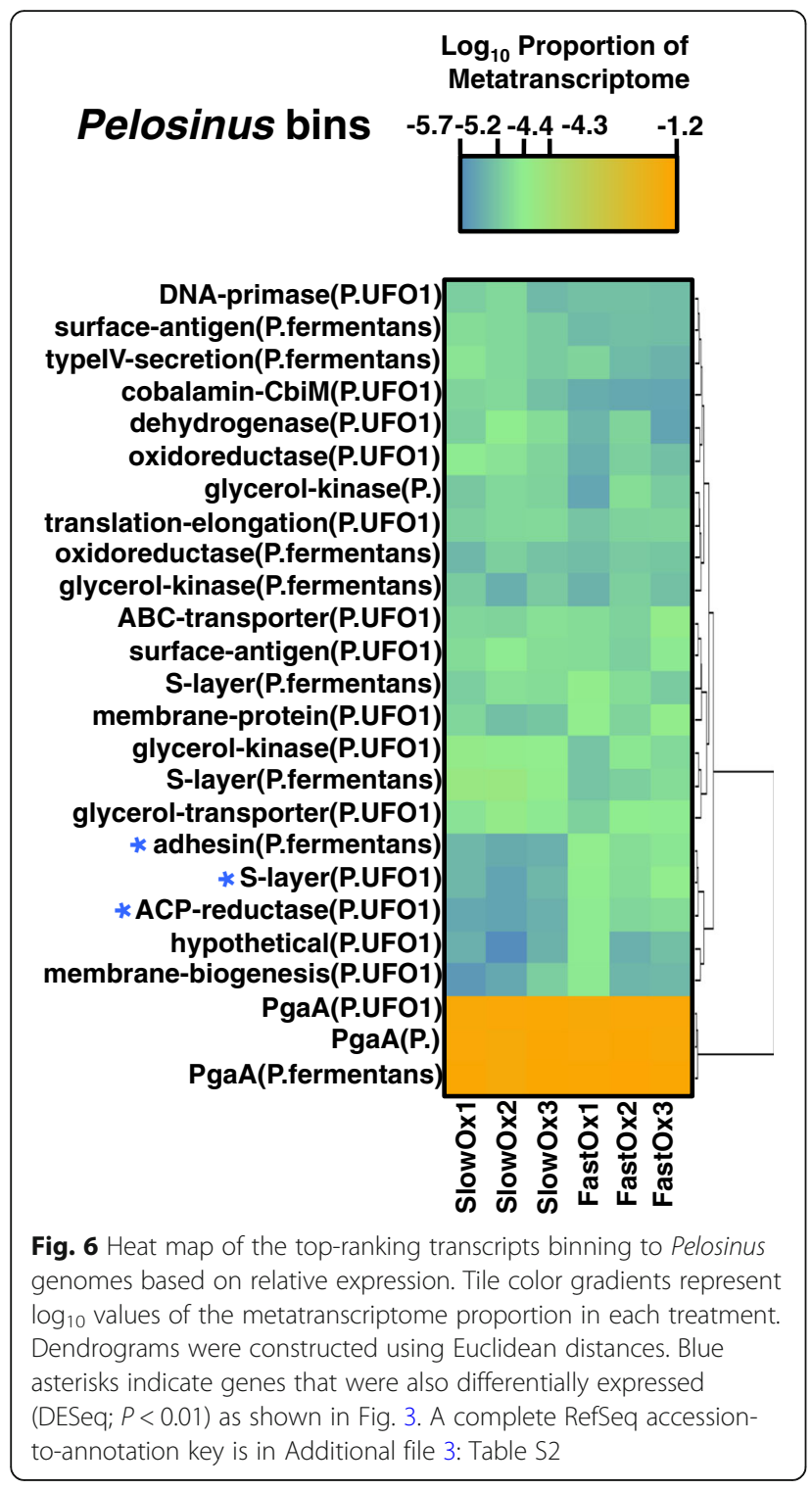

\section{Discussion}

This study examined Fe crystallinity transformations and $\mathrm{Fe}(\mathrm{III})$-reducer gene expression in anoxic humid-forest soil microcosms repeatedly exposed to pulsed oxygenation at either a fast or slow rate. This experimental methodology served as an analog for redox-fluctuating conditions expected to occur in moist aggregates/microsites during wetting and drying of the bulk soil matrix.

\section{Fe crystallinity depends on oxygenation rates during redox oscillations}

We tested the hypothesis that slow oxygenation rates lead to the buildup of more crystalline Fe(III) phases during soil redox oscillations. The Mössbauer data support this hypothesis, showing that slower oxygenation resulted in higher $\mathrm{Fe}(\mathrm{III})$-(oxyhydr)oxide crystallinity than faster oxygenation (Fig. 1b and Additional file 1: Section 2). We expect that different $\mathrm{Fe}(\mathrm{II})$ oxidation rates strongly contributed to this result [52, 55, 71]. However, higher Fe(II) concentrations near the end of 16 and 24 day oxic intervals in the slow oxygenation treatment may have also promoted more crystal ripening (Ostwald) than in the fast treatment by facilitating greater abiotic electron transfer and re-crystallization $[8,58,62]$. This might also explain why both treatments showed significantly higher Fe crystallinity than the initial soil, since both treatments experienced elevated levels of $\mathrm{Fe}(\mathrm{II})$ during the incubation (Fig. 1a-b). Additionally, because the degree to which organic and inorganic substances are incorporated in de novo $\mathrm{Fe}(\mathrm{III})$ solids during precipitation is directly related to precipitation rate $[72,73]$, the fast treatment may have resulted in lower Fe crystallinity due to more precipitation of substituted Fe phases compared to in the slow treatment. Toward the end of incubation, Fe(II) in the solid phase began to plateau at $c a 300 \mathrm{mmol} \mathrm{kg}$ soil in both treatments (Fig. 1a), which is consistent with Fe(II) sorption (Additional file 1: Figure S13). This accumulated $\mathrm{Fe}(\mathrm{II})$ may have blocked some (oxyhydr)oxide surfaces during microbial Fe(III) reduction [19]. The weakly magnetic Fe(II) phase detected in all samples at $4.5 \mathrm{~K}$ is consistent with the sorption of biogenic $\mathrm{Fe}$ (II) to magnetically ordered $\mathrm{Fe}(\mathrm{III})$ phases, or possibly the presence/formation of magnetite [74] (Additional file 1: Figures S6-S8).

\section{$\mathrm{Fe}(\mathrm{III})$-reducer gene expression in the soil microbiome} reflects transformations in Fe crystallinity

Our data suggest that the strategies of $\mathrm{Fe}(\mathrm{III})$ reduction by native soil $\mathrm{Fe}(\mathrm{III})$ reducers are both sensitive to and indicative of relatively small differences in Fe(III) crystallinity induced by repeated $\mathrm{O}_{2}$ pulses at different rates. Subtle changes in the reactivity of various synthetic Fe minerals have also been shown to finely regulate $\mathrm{Fe}(\mathrm{III})$-reduction pathways in pure culture experiments [32]. We observed several significant differences in relative gene expression between treatments that are consistent with microbial strategies for adapting to shifts in soil Fe mineral crystallinity $[39,42,65]$. One particular multiheme cytochrome $c$ gene encoding a type-III fibronectin domain was expressed significantly higher in the slow treatment (Fig. 4), which suggests that fibronectin-like domains play a unique role in cytochrome-dependent extracellular electron transport in soil during increases in Fe mineral crystallinity. Overall, diverse $\mathrm{Fe}(\mathrm{III})$-reducer functions were associated with type-III fibronectin domains in our experiment, which supports and broadens the results of earlier studies $[42,75]$. The omcA/mtrC gene has been shown to be more essential for extracellular electron transfer during growth with $\mathrm{Fe}(\mathrm{III})$-(oxyhydr)oxide compared to Fe(III)-citrate [39]; however, our data indicate 
that this gene is also sensitive to differences in soil Fe(III) crystallinity, being expressed significantly higher in the fast oxygenation treatment compared to slow oxygenation (Fig. 3). Flagellin genes and a type-IV pilO-homology gene in our study appeared to be more essential during reduction of less crystalline $\mathrm{Fe}(\mathrm{III})$ phases in the fast oxygenation treatment compared to the slow treatment (Fig. 3). Expression of flagellin genes was shown previously to increase $\geq 30$ fold in G. metallireducens when grown on $\mathrm{Fe}(\mathrm{III})$-(oxyhydr)oxide compared to $\mathrm{Fe}(\mathrm{III})$-citrate [39] and are thought to be important for Fe mineral surface sensing and congregation at the mineral-microbe interface $[33,37,40]$. The expression of a pilO-like gene in our study was possibly involved in the formation of microbial nanowires that may be used to transfer electrons to mineral surfaces and/or other neighboring cells [76]. The significantly higher expression of flagellin and pilin genes in the fast oxygenation treatment also contrasts previous research [31] that showed significant downregulation of similar genes under $\mathrm{O}_{2}$ exposure and oxidative stress. Accordingly, the significantly higher expression of these genes observed in our fast oxygenation treatment under anoxic conditions supports our conclusion that flagellin and pilin gene expression reflected differences in Fe crystallinity during our experiment, and not oxidative stress.

The high metatranscriptomic contribution of transcripts recruiting to Pelosinus in both treatments (Additional file 1: Figure S3) may reflect the general availability of short range ordered (SRO) Fe phases in the soil [66, 77]. However, significantly higher relative expression of Pelosinus S-layer and adhesin genes (Fig. 3) is consistent with the more abundant SRO Fe(III) phases in the fast oxygenation treatment compared to the slow treatment. S-layer and adhesin proteins can be used by bacteria to transport mammalian heme to supply Fe during pathogenesis [78, 79]; therefore, it may be that $\mathrm{Fe}(\mathrm{III})$ reducers in soil can bind and transport Fe using similar mechanisms. Accordingly, Thorgersen et al. [68] has recently shown that large, highly expressed, S-layer complexes in Pelosinus UFO1 can bind heavy metals such as U(IV). The significantly higher relative expression of a heavy metal transport/cytochrome $c$ biogenesis gene of Pelosinus in the fast oxygenation treatment also suggests a specific activity and function toward the reduction of more SRO $\mathrm{Fe}(\mathrm{III})$ phases, though it remains unclear if Pelosinus species can use cytochrome-mediated electron transfer to reduce $\mathrm{Fe}(\mathrm{III})$ [67]. Corrinoid (e.g., vitamin $\mathrm{B}_{12}$ ) genes matching to Pelosinus appear to have been more essential in the slow oxygenation treatment (Fig. 4), consistent with the higher relative expression of cbiM (which is involved in the uptake of Co atoms) of Pelosinus UFO1 in the slow treatment (Fig. 6). The enzymes encoded by pdgle and $c b i Q$ are required for the transport of cobalt and the initial steps of corrinoid synthesis, while the enzyme encoded by
cobT is required for catalyzing attachment of precursor components of vitamin $B_{12}[80,81]$. Fluctuation in corrinoid production in response to different rates of transient oxygenation is of broad ecological interest because corrinoids are required by many organisms, yet are synthesized de novo only by select microorganisms (e.g., Pelosinus) [81]. We postulate that corrinoids produced by Pelosinus may also be important for electron mediation between the cell and Fe-(oxyhydr)oxides in soils, considering that pure corrinoids can act as effective electron mediators [82]. Hypothetically, corrinoids in the slow oxygenation treatment could have helped to catalyze the transfer of electrons to more crystalline $\mathrm{Fe}(\mathrm{III})$-(oxyhydr)oxides or shuttled electrons to more available/reactive $\mathrm{Fe}(\mathrm{III})$ sites in our study. The high relative expression of Pelosinus genes that share homology with pgaA (Fig. 6) indicates that extracellular matrix formation is important during $\mathrm{Fe}(\mathrm{III})$-reducing conditions in soil, which is consistent with recent laboratory culture experiments $[68,69]$. This is further supported by our data that suggest genes encoding other extracellular features of Pelosinus, such as S-layer complexes and adhesins, are regulated by changes in Fe crystal order (Figs. 3 and 6). Further, the expression of type-IV secretion, surface antigen and bacteriocin genes (Figs. 3 and 6) indicates that specific pathogenic interactions might confer a competitive advantage to Pelosinus under $\mathrm{Fe}(\mathrm{III})$-reducing conditions, which could help explain the predominance of Pelosinus in many anaerobic and heavy-metal-contaminated environments [66, 83, 84]. Interestingly, the differential expression of the Pelosinus bacteriocin gene in our study, a gene that putatively encodes an anti-microbial toxin against other closely related taxa, was significantly higher in the fast oxygenation treatment compared to the slow treatment (Fig. 3), perhaps indicating an increase in direct competition between Pelosinus and other $\mathrm{Fe}(\mathrm{III})$ reducers during reduction of more abundant SRO Fe(III)-(oxyhydr)oxides following rapid oxygenation.

\section{The microbiome of anoxic soil is regulated by transient oxygenation events}

Overall, oxygenation patterns caused distinct metatranscriptomic profiles despite samples being anoxic for $90 \%$ of the incubation time and the collection of RNA occurring after a final 7-day period of anoxic conditions (Fig. 2 and Additional file 1: Figures S3-S5). We found that the relative transcript abundance for archaeal $\mathrm{CH}_{4}$-producing Methanobacterium was significantly higher in the fast oxygenation treatment compared to the slow treatment and was the only primary methanogenic genus that ranked in the top 50 transcript-recruiting genomes (Additional file 1: Figure S3). Species assignments included M. arcticum, M. formicicum, M. lacus, M. paludis, 


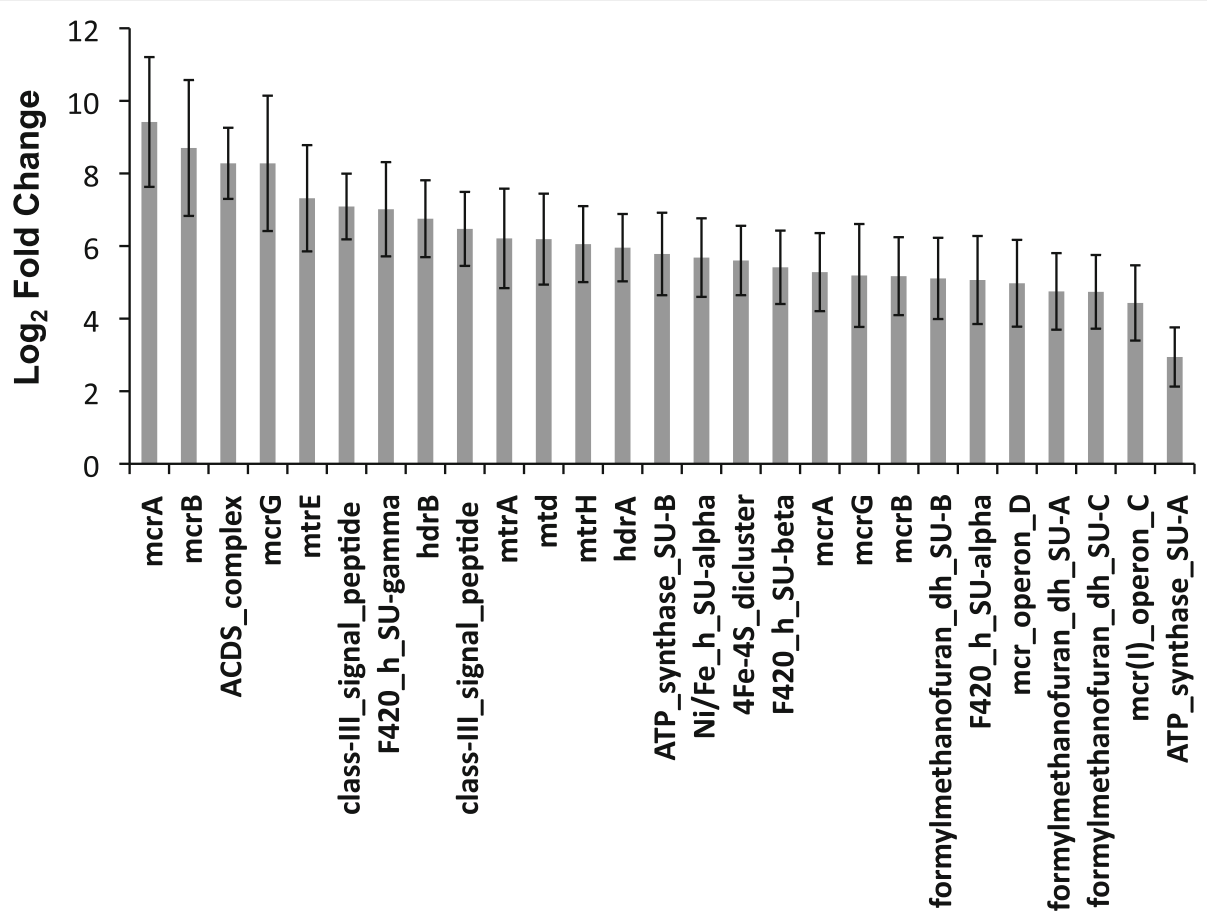

Fig. 7 Top differentially expressed genes of Methanobacterium detected at significantly higher levels in the fast oxygenation treatment (DESeq; $P$ $<0.01)$. Bars indicate means ( \pm s.e.) $(n=3)$. A complete RefSeq accession-to-annotation key is given in Additional file 3: Table S2

and strain SMA-27. All diagnostic Methanobacterium genes required for the $\mathrm{H}_{2} / \mathrm{CO}_{2}$ pathway to $\mathrm{CH}_{4}$ (i.e., hydrogenotrophic methanogenesis) were expressed significantly higher in the fast oxygenation treatment (Fig. 7), including those encoding acetyl-CoA dehydrogenase/synthase (ACDS complex) and methyl coenzyme M reductase subunits (mcrABG) (Fig. 7). Transcripts for two class (III) signal peptide genes putatively involved in the synthesis of type-IV pilus-like structures were also significantly enriched in the fast oxygenation treatment with similar $\log _{2}$ fold changes as the essential $\mathrm{H}_{2} / \mathrm{CO}_{2}$ to $\mathrm{CH}_{4}$ pathway genes. This finding suggests that the rate of $\mathrm{O}_{2}$ influx during transient oxygenation events regulates both the timing and biological pathway of methanogenesis occurring under predominantly anoxic conditions in soil microbiomes. There was also evidence that different cytochrome oxidases may have been selected to mitigate oxidative stress under different oxygenation conditions, with significantly higher expression of cytochrome $o$ ubiquinol oxidase SU2 transcripts in the slow treatment and of cytochrome $c$ $c b b_{3}$-type oxidase SU1 transcripts in the fast treatment (Additional file 1: Figure S5). Similar enzymes have been shown to be important during redox transitions [31] and during reduction of insoluble metal oxides [65]. We further speculate that production of these enzymes under anoxic conditions in a redox-dynamic system may poise cells to tolerate transient oxygenation events $[31,85,86]$.

\section{Conclusions}

We found that the rate of $\mathrm{O}_{2}$ delivery during transient oxygenation events in anoxic soil suspensions can influence Fe(III) crystallinity and the expression of specific genes required for $\mathrm{Fe}(\mathrm{III})$ reducers to transfer electrons, interact with surfaces, and interact with other cells. Importantly, these data suggest that soil Fe(III) reducers regulate gene expression in response to small differences in Fe-(oxyhydr)oxide crystallinity induced by different oxygenation rates. Overall, our work demonstrates that transient oxygenation events have the potential to direct specific anaerobic pathways and the biogeochemical cycling of $\mathrm{Fe}$ and $\mathrm{C}$ in humid forest soils. Similar transient oxygenation events are expected to occur in many natural environments, where dynamic changes in water-table depth, irrigation practices, or precipitation can drive redox-dynamic conditions. More broadly, our data suggest that transient oxygenation events in low- $\mathrm{O}_{2}$ environments may have global importance due to their effect on key microbial processes that hinge on Fe cycling, including $\mathrm{C}$ turnover rates, greenhouse gas emissions, and nutrient availability. 


\section{Additional files}

Additional file 1: Supplemental text and figures that give additional information on experimental design and metatranscriptomics (section 1), and Mössbauer spectroscopy (section 2). (PDF 2285 kb)

Additional file 2: Table S1. Gives an accounting of sequence reads through processing, reference searching, and binning. (XLSX $45 \mathrm{~kb}$ )

Additional file 3: Table S2. Lists a key for linking NCBI RefSeq accessions to corresponding functional annotations used in main Figs. 3, 4, 5, 6, and 7. (XLSX $63 \mathrm{~kb})$

Additional file 4: Table S3. Gives Mössbauer parameters for spectra recorded at $140 \mathrm{~K}$. (XLSX $49 \mathrm{~kb})$

Additional file 5: Table S4. Gives Mössbauer parameters for spectra recorded at $77 \mathrm{~K}$. (XLSX $48 \mathrm{~kb}$ )

Additional file 6: Table S5. Gives Mössbauer parameters for spectra recorded at $4.5 \mathrm{~K}$. (XLSX $48 \mathrm{~kb})$

Additional file 7: Table S6. Gives Mössbauer parameters for spectra recorded at $295 \mathrm{~K}$. (XLSX $47 \mathrm{~kb}$ )

\section{Acknowledgements}

We thank Whendee Silver (UC Berkeley) and Steven Hall (U lowa) for providing access to the Bisley site; Nehru Mantripragada (Crop and Soil Science Dept., University of Georgia (UGA)) for the laboratory assistance: Edward T. Kipreos (Dept. of Cellular Biology, UGA) for the use of laboratory space and equipment; and Katherine Sandlin and Roger Nilsen of the Georgia Genomics and Bioinformatics Core (GGBC), Athens, GA for cDNA library construction, Illumina sequencing, and consultation. We also acknowledge the Georgia Advanced Computing Resource Center (GACRC) at UGA for the Linux system use during the meta-data handling and processing.

\section{Funding}

This work was funded by USDA-NIFA Soil Processes Program AFRI-NIFA Grant no. 2009-65107-05830 and NSF grants EAR-1331841, EAR-1053470, EAR1451508, and DEB-1457761. Sequencing was partially funded by the UGA graduate school Innovative and Interdisciplinary Research Award.

\section{Availability of data and materials}

All original sequence data can be found under BioProject PRJNA381321 in the NCBI SRA database (https://www.ncbi.nlm.nih.gov/Traces/study/ ?acc=SRP103306). Corresponding sample accessions are also listed in Additional file 2, Table S1.

\section{Authors' contributions}

JLW and AT conceived of the project and designed the experiment. JLW conducted the experiment and performed all the measurements and analyses with assistance from MAM on the metatranscriptomics and from AT on the Mössbauer spectroscopy. JLW led the manuscript preparation with AT serving as the primary editor. All authors read and approved the final manuscript.

\section{Ethics approval and consent to participate}

Not applicable

\section{Consent for publication}

Not applicable

\section{Competing interests}

The authors declare that they have no competing interests.

\section{Publisher's Note}

Springer Nature remains neutral with regard to jurisdictional claims in published maps and institutional affiliations.

\section{Author details}

Department of Crop and Soil Sciences, University of Georgia, Athens 30602 GA, USA. ²Department of Marine Sciences, University of Georgia, Athens, GA, USA.

Received: 15 May 2018 Accepted: 9 October 2018

Published online: 23 October 2018

\section{References}

1. Sexstone AJ, Revsbech NP, Parkin TB, Tiedje JM. Direct measurement of oxygen profiles and denitrification rates in soil aggregates. Soil Sci Soc Am J. 1985;49:645-51.

2. Hall SJ, McDowell WH, Silver WL. When wet gets wetter: decoupling of moisture, redox biogeochemistry, and greenhouse gas fluxes in a humid tropical forest soil. Ecosystems. 2013;16:576-89.

3. Dubinsky EA, Silver WL, Firestone MK. Tropical forest soil microbial communities couple iron and carbon biogeochemistry. Ecology. 2010;91: 2604-12.

4. Keiluweit M, Gee K, Denney A, Fendorf S. Anoxic microsites in upland soils dominantly controlled by clay content. Soil Biol Biochem. 2018;118:42-50.

5. Mejia J, Roden EE, Ginder-Vogel M. Influence of oxygen and nitrate on fe (hydr)oxide mineral transformation and soil microbial communities during redox cycling. Environ Sci Technol. 2016;50:3580-8.

6. Ginn B, Meile C, Wilmoth J, Tang YZ, Thompson A. Rapid iron reduction rates are stimulated by high-amplitude redox fluctuations in a tropical forest soil. Environ Sci Technol. 2017:51:3250-9.

7. Barcellos D, Cyle KT, Thompson A. Faster redox fluctuations can lead to higher iron reduction rates in humid forest soils. Biogeochemistry. 2018;137:367-78.

8. Hansel CM, Benner SG, Neiss J, Dohnalkova A, Kukkadapu RK, Fendorf S. Secondary mineralization pathways induced by dissimilatory iron reduction of ferrihydrite under advective flow. Geochim Cosmochim Acta. 2003;67: 2977-92.

9. Bonneville S, Behrends T, Van Cappellen P. Solubility and dissimilatory reduction kinetics of iron(iii) oxyhydroxides: a linear free energy relationship. Geochim Cosmochim Acta. 2009:73:5273-82.

10. Murad E. Mossbauer spectroscopy of clays, soils and their mineral constituents. Clay Minerals. 2010:45:413-30.

11. Adhikari D, Zhao Q, Das K, Mejia J, Huang RX, Wang XL, Poulson SR, Tang $Y Z$, Roden EE, Yang Y. Dynamics of ferrihydrite-bound organic carbon during microbial Fe reduction. Geochim Cosmochim Acta. 2017;212:221-33.

12. Wu T, Shelobolina $E_{1} X u H$, Konishi H, Kukkadapu R, Roden EE. Isolation and microbial reduction of Fe(III) phyllosilicates from subsurface sediments. Environ Sci Technol. 2012;46:11618-26.

13. Amstaetter $\mathrm{K}$, Borch T, Kappler A. Influence of humic acid imposed changes of ferrihydrite aggregation on microbial Fe(III) reduction. Geochim Cosmochim Acta. 2012;85:326-41.

14. Shimizu M, Zhou JH, Schroder C, Obst M, Kappler A, Borch T. Dissimilatory reduction and transformation of ferrihydrite-humic acid coprecipitates. Environ Sci Technol. 2013;47:13375-84.

15. Lalonde K, Mucci A, Ouellet A, Gelinas Y. Preservation of organic matter in sediments promoted by iron. Nature. 2012;483:198-200.

16. Eusterhues K, Rennert T, Knicker H, Kogel-Knabner I, Totsche KU, Schwertmann $U$. Fractionation of organic matter due to reaction with ferrihydrite: coprecipitation versus adsorption. Environ Sci Technol. 2011;45:527-33.

17. Finley BK, Dijkstra P, Rasmussen C, Schwartz E, Mau RL, Liu XJA, Van Gestel $\mathrm{N}$, Hungate BA. Soil mineral assemblage and substrate quality effects on microbial priming. Geoderma. 2018;322:38-47.

18. Peretyazhko T, Sposito G. Iron(III) reduction and phosphorous solubilization in humid tropical forest soils. Geochim Cosmochim Acta. 2005;69:3643-52.

19. Roden EE. Geochemical and microbiological controls on dissimilatory iron reduction. Compt Rendus Geosci. 2006;338:456-67.

20. Roden EE. Microbial iron-redox cycling in subsurface environments. Biochem Soc Trans. 2012:40:1249-56

21. Bonneville S, Van Cappellen P, Behrends T. Microbial reduction of iron(III) oxyhydroxides: effects of mineral solubility and availability. Chem Geol. 2004:212:255-68.

22. Coby AJ, Picardal F, Shelobolina E, Xu HF, Roden EE. Repeated anaerobic microbial redox cycling of iron. Appl Environ Microbiol. 2011:77:6036-42.

23. Lonergan DJ, Jenter HL, Coates JD, Phillips EJP, Schmidt TM, Lovley DR. Phylogenetic analysis of dissimilatory Fe(III)-reducing bacteria. J Bacteriol. 1996;178:2402-8. 
24. Liang $Y T$, Van Nostrand JD, N'Guessan LA, Peacock AD, Deng Y, Long PE, Resch CT, Wu LY, He ZL, Li GH, et al. Microbial functional gene diversity with a shift of subsurface redox conditions during in situ uranium reduction. Appl Environ Microbiol. 2012;78:2966-72.

25. Kato S, Hashimoto K, Watanabe K. Microbial interspecies electron transfer via electric currents through conductive minerals. Proc Natl Acad Sci U S A. 2012;109:10042-6.

26. Parsons $C T$, Couture R-M, Omoregie EO, Bardelli F, Greneche J-M, RomanRoss $G$, Charlet $L$. The impact of oscillating redox conditions: arsenic immobilisation in contaminated calcareous floodplain soils. Environ Pollut. 2013;178:254-63.

27. Vogelsang V, Fiedler S, Jahn R, Kaiser K. In-situ transformation of ironbearing minerals in marshland-derived paddy subsoil. Eur J Soil Sci. 2016;67: 676-85

28. Ding LJ, Su JQ, Xu HJ, Jia ZJ, Zhu YG. Long-term nitrogen fertilization of paddy soil shifts iron-reducing microbial community revealed by rna-c-13acetate probing coupled with pyrosequencing. ISME J. 2015;9:721-34.

29. LaRowe DE, Van Cappellen P. Degradation of natural organic matter: a thermodynamic analysis. Geochim Cosmochim Acta. 2011;75:2030-42.

30. Keiluweit M, Wanzek T, Kleber M, Nico P, Fendorf S. Anaerobic microsites have an unaccounted role in soil carbon stabilization. Nat Commun. 2017; 8(1):1771.

31. Mouser PJ, Holmes DE, Perpetua LA, DiDonato R, Postier B, Liu A, Lovley DR. Quantifying expression of geobacter spp. oxidative stress genes in pure culture and during in situ uranium bioremediation. ISME J. 2009;3:454-65.

32. Levar CE, Hoffman CL, Dunshee AJ, Toner BM, Bond DR. Redox potential as a master variable controlling pathways of metal reduction by geobacter sulfurreducens. ISME J. 2017;11:741-52.

33. Merkley ED, Wrighton KC, Castelle CJ, Anderson BJ, Wilkins MJ, Shah V, Arbour T, Brown JN, Singer SW, Smith RD, Lipton MS. Changes in protein expression across laboratory and field experiments in geobacter bemidjiensis. J Proteome Res. 2015;14:1361-75.

34. Komlos J, Kukkadapu RK, Zachara JM, Jaffe PR. Biostimulation of iron reduction and subsequent oxidation of sediment containing Fe-silicates and Fe-oxides: effect of redox cycling on Fe(III) bioreduction. Water Res. 2007;41: 2996-3004.

35. Zachara JM, Fredrickson JK, Li SM, Kennedy DW, Smith SC, Gassman PL. Bacterial reduction of crystalline Fe3+ oxides in single phase suspensions and subsurface materials. Am Mineral. 1998;83:1426-43.

36. Tufano KJ, Benner SG, Mayer KU, Marcus MA, Nico PS, Fendorf S. Aggregatescale heterogeneity in iron (hydr)oxide reductive transformations. Vadose Zone J. 2009:8:1004-12.

37. Childers SE, Ciufo S, Lovley DR. Geobacter metallireducens accesses insoluble Fe(III) oxide by chemotaxis. Nature. 2002:416:767-9.

38. Gorby YA, Yanina S, McLean JS, Rosso KM, Moyles D, Dohnalkova A, Beveridge TJ, Chang IS, Kim BH, Kim KS, et al. Electrically conductive bacterial nanowires produced by Shewanella oneidensis strain $\mathrm{mr}-1$ and other microorganisms. Proc Natl Acad Sci U S A. 2006;103:11358-63.

39. Smith JA, Lovley DR, Tremblay PL. Outer cell surface components essential for Fe(III) oxide reduction by Geobacter metallireducens. Appl Environ Microbiol. 2013;79:901-7.

40. Harris HW, El-Naggar MY, Nealson KH. Shewanella oneidensis mr-1 chemotaxis proteins and electron-transport chain components essential for congregation near insoluble electron acceptors. Biochem Soc Trans. 2012; 40:1167-U1129.

41. Walker DJF, Adhikari RY, Holmes DE, Ward JE, Woodard TL, Nevin KP, Lovley DR. Electrically conductive pili from pilin genes of phylogenetically diverse microorganisms. ISME J. 2018;12:48-58.

42. Holmes DE, Mester T, O'Neil RA, Perpetua LA, Larrahondo MJ, Glaven R, Sharma ML, Ward JE, Nevin KP, Lovley DR. Genes for two multicopper proteins required for Fe(III) oxide reduction in Geobacter sulfurreducens have different expression patterns both in the subsurface and on energyharvesting electrodes. Microbiol-Sgm. 2008;154:1422-35.

43. Zacharoff LA, Morrone DJ, Bond DR. Geobacter sulfurreducens extracellular multiheme cytochrome pgca facilitates respiration to fe(iii) oxides but not electrodes. Front Microbiol. 2017:8:2481.

44. Marsili E, Baron DB, Shikhare ID, Coursolle D, Gralnick JA, Bond DR. Shewanella secretes flavins that mediate extracellular electron transfer. Proc Natl Acad Sci U S A. 2008;105:3968-73.

45. Holmes DE, Shrestha PM, Walker DJF, Dang Y, Nevin KP, Woodard TL, Lovley DR. Metatranscriptomic evidence for direct interspecies electron transfer between Geobacter and Methanothrix species in methanogenic rice paddy soils. Appl Environ Microbiol. 2017;83:e00223-17. https://doi.org/10.1128/ AEM.00223-17.

46. Holmes DE, O'Neil RA, Chavan MA, N'Guessan LA, Vrionis HA, Perpetua LA Larrahondo MJ, DiDonato R, Liu A, Lovley DR. Transcriptome of Geobacter uraniireducens growing in uranium-contaminated subsurface sediments. ISME J. 2009;3:216-30.

47. Pallud C, Kausch M, Fendorf S, Meile C. Spatial patterns and modeling of reductive ferrihydrite transformation observed in artificial soil aggregates. Environ Sci Technol. 2010:44:74-9.

48. Hansel CM, Benner SG, Nico P, Fendorf S. Structural constraints of ferric (hydr)oxides on dissimilatory iron reduction and the fate of Fe(II). Geochim Cosmochim Acta. 2004:68:3217-29.

49. Sjöstedt C, Persson I, Hesterberg D, Kleja DB, Borg H, Gustafsson JP. Iron speciation in soft-water lakes and soils as determined by exafs spectroscopy and geochemical modelling. Geochim Cosmochim Acta. 2013;105:172-86.

50. Bigham JM, Golden DC, Bowen LH, Buol SW, Weed SB. Iron-oxide mineralogy of well-drained ultisols and oxisols .1. Characterization of ironoxides in soil clays by mossbauer-spectroscopy, $\mathrm{x}$-ray-diffractometry, and selected chemical techniques. Soil Sci Soc Am J. 1978;42:816-25.

51. Thompson A, Rancourt DG, Chadwick OA, Chorover J. Iron solid-phase differentiation along a redox gradient in basaltic soils. Geochim Cosmochim Acta. 2011;75:119-33.

52. Carlson $L$, Schwertmann $U$. The effect of $\mathrm{co} 2$ and oxidation rate on the formation of goethite versus lepidocrocite from an Fe(II) system at ph- 6 and ph-7. Clay Miner. 1990;25:65-71.

53. Schwertmann U, Cornell RM: Iron oxides in the laboratory preparation and characterization. 1991.

54. Steefel $\mathrm{Cl}$, Vancappellen P. A new kinetic approach to modeling water-rock interaction - the role of nucleation, precursors, and Ostwald ripening. Geochim Cosmochim Acta. 1990;54:2657-77.

55. Chen $\mathrm{CM}$, Thompson A. Ferrous iron oxidation under varying po(2) levels: the effect of Fe(III)/AI(III) oxide minerals and organic matter. Environ Sci Technol. 2018;52:597-606.

56. Hansel CM, Benner SG, Fendorf S. Competing Fe(ii)-induced mineralization pathways of ferrihydrite. Environ Sci Technol. 2005:39:7147-53.

57. Thompson A, Chadwick OA, Rancourt DG, Chorover J. Iron-oxide crystallinity increases during soil redox oscillations. Geochim Cosmochim Acta. 2006;70: 1710-27.

58. Tomaszewski EJ, Cronk SS, Gorski CA, Ginder-Vogel M. The role of dissolved Fe(II) concentration in the mineralogical evolution of Fe (hydr)oxides during redox cycling. Chem Geol. 2016;438:163-70.

59. Li YC, Yu S, Strong J, Wang HL. Are the biogeochemical cycles of carbon, nitrogen, sulfur, and phosphorus driven by the "Fe-III-Fe-II redox wheel" in dynamic redox environments? J Soils Sediments. 2012;12:683-93.

60. Scharer M, De Grave E, Semalulu O, Sinaj S, Vandenberghe RE, Frossard E. Effect of redox conditions on phosphate exchangeability and iron forms in a soil amended with ferrous iron. Eur J Soil Sci. 2009;60:386-97.

61. DeAngelis KM, Silver WL, Thompson AW, Firestone MK. Microbial communities acclimate to recurring changes in soil redox potential status. Environ Microbiol. 2010;12:3137-49.

62. Tishchenko V, Meile C, Scherer MM, Pasakarnis TS, Thompson A. Fe2+ catalyzed iron atom exchange and re-crystallization in a tropical soil. Geochim Cosmochim Acta. 2015;148:191-202.

63. Gifford SM, Sharma S, Rinta-Kanto JM, Moran MA. Quantitative analysis of a deeply sequenced marine microbial metatranscriptome. ISME J. 2011;5:461-72.

64. Tveit AT, Urich T, Svenning MM. Metatranscriptomic analysis of arctic peat soil microbiota. Appl Environ Microbiol. 2014;80:5761-72.

65. Nissen S, Liu XX, Chourey K, Hettich RL, Wagner DD, Pfiffner SM, Loffler FE. Comparative c-type cytochrome expression analysis in Shewanella oneidensis strain mr-1 and Anaeromyxobacter dehalogenans strain 2CP-C grown with soluble and insoluble oxidized metal electron acceptors. Biochem Soc Trans. 2012;40:1204-U1268.

66. Mosher JJ, Phelps TJ, Podar M, Hurt RA, Campbell JH, Drake MM, Moberly JG, Schadt CW, Brown SD, Hazen TC, et al. Microbial community succession during lactate amendment and electron acceptor limitation reveals a predominance of metal-reducing Pelosinus spp. Appl Environ Microbiol. 2012;78:2082-91.

67. Beller HR, Han RY, Karaoz U, Lim H, Brodie EL. Genomic and physiological characterization of the chromate-reducing, aquifer-derived Firmicute Pelosinus sp strain HCF1. Appl Environ Microbiol. 2013;79:63-73. 
68. Thorgersen MP, Lancaster WA, Rajeev L, Ge XX, Vaccaro BJ, Poole FL, Arkin AP, Mukhopadhyay A, Adamsa MWW. A highly expressed high-molecularweight S-layer complex of Pelosinus sp strain UFO1 binds uranium. Appl Environ Microbiol. 2017;83(4):e03044-16.

69. Ray AE, Connon SA, Neal AL, Fujita Y, Cummings DE, Ingram JC, Magnuson TS. Metal transformation by a novel pelosinus isolate from a subsurface environment. Front Microbiol. 2018;9:1689. https://doi.org/10.3389/fmicb. 2018.01689

70. Llauro A, Guerra P, Kant R, Bothner B, Verdaguer N, de Pablo PJ. Decrease in ph destabilizes individual vault nanocages by weakening the inter-protein lateral interaction. Sci Rep. 2016;6:34143.

71. Park B, Dempsey BA. Heterogeneous oxidation of Fe(II) on ferric oxide at neutral ph and a low partial pressure of 0(2). Environ Sci Technol. 2005;39: 6494-500.

72. Mikutta C, Mikutta R, Bonneville S, Wagner F, Voegelin A, Christl I, Kretzschmar R. Synthetic coprecipitates of exopolysaccharides and ferrihydrite. Part i: characterization. Geochim Cosmochim Acta. 2008;72: 1111-27.

73. Waychunas GA, Kim CS, Banfield JF. Nanoparticulate iron oxide minerals in soils and sediments: unique properties and contaminant scavenging mechanisms. J Nanopart Res. 2005;7:409-33.

74. Kukkadapu RK, Zachara JM, Fredrickson JK, McKinley JP, Kennedy DW, Smith SC, Dong HL. Reductive biotransformation of Fe in shale-limestone saprolite containing $\mathrm{Fe}$ (III) oxides and $\mathrm{Fe}$ (II)/Fe(III) phyllosilicates. Geochim Cosmochim Acta. 2006;70:3662-76.

75. Mehta T, Childers SE, Glaven R, Lovley DR, Mester T. A putative multicopper protein secreted by an atypical type II secretion system involved in the reduction of insoluble electron acceptors in Geobacter sulfurreducens. Microbiology-Sgm. 2006;152:2257-64.

76. Chan CH, Levar CE, Jimenez-Otero F, Bond DR. Genome scale mutational analysis of Geobacter sulfurreducens reveals distinct molecular mechanisms for respiration and sensing of poised electrodes versus Fe(III) oxides. J Bacteriol. 2017;199:JB.00340-17. https://doi.org/10.1128/JB.00340-17.

77. Brown SD, Podar M, Klingeman DM, Johnson CM, Yang ZK, Utturkar SM, Land ML, Mosher JJ, Hurt RA, Phelps TJ, et al. Draft genome sequences for two metal-reducing Pelosinus fermentans strains isolated from a Cr(VI)contaminated site and for type strain R7. J Bacteriol. 2012;194:5147-8.

78. Fagan RP, Fairweather NF. Biogenesis and functions of bacterial S-layers. Nat Rev Microbiol. 2014;12:211-22.

79. Tarlovsky Y, Fabian M, Solomaha E, Honsa E, Olson JS, Maresso AW. A Bacillus anthracis S-layer homology protein that binds heme and mediates heme delivery to IsdC. J Bacteriol. 2010;192:3503-11.

80. Yan J, Simsir B, Farmer AT, Bi M, Yang Y, Campagna SR, Loffler FE. The corrinoid cofactor of reductive dehalogenases affects dechlorination rates and extents in organohalide-respiring Dehalococcoides mecartyi. ISME J. 2016;10:1092-101.

81. Hazra AB, Han AW, Mehta AP, Mok KC, Osadchiy V, Begley TP, Taga ME. Anaerobic biosynthesis of the lower ligand of vitamin b-12. Proc Natl Acad Sci U S A. 2015;112:10792-7.

82. Giedyk M, Goliszewska K, Gryko D. Vitamin b-12 catalysed reactions. Chem Soc Rev. 2015;44:3391-404.

83. Han N, Yu WW, Qiang YJ, Zhang W. T4sp database 2.0: an improved database for type IV secretion systems in bacterial genomes with new online analysis tools. Comput Math Methods Med. 2016;4. Article ID 9415459. http://dx.doi.org/10.1155/2016/9415459.

84. Men YJ, Seth EC, Yi S, Allen RH, Taga ME, Alvarez-Cohen L. Sustainable growth of Dehalococcoides mccartyi 195 by corrinoid salvaging and remodeling in defined lactate-fermenting consortia. Appl Environ Microbiol. 2014;80:2133-41.

85. Ekici S, Pawlik G, Lohmeyer E, Koch HG, Daldal F. Biogenesis of cbb(3)-type cytochrome c oxidase in Rhodobacter capsulatus. BBA-Bioenergetics. 2012; 1817:898-910.

86. Jewell TNM, Karaoz U, Brodie EL, Williams KH, Beller HR. Metatranscriptomic evidence of pervasive and diverse chemolithoautotrophy relevant to C, S, N and Fe cycling in a shallow alluvial aquifer. ISME J. 2016;10:2106-17.

\section{Ready to submit your research? Choose BMC and benefit from:}

- fast, convenient online submission

- thorough peer review by experienced researchers in your field

- rapid publication on acceptance

- support for research data, including large and complex data types

- gold Open Access which fosters wider collaboration and increased citations

- maximum visibility for your research: over $100 \mathrm{M}$ website views per year

At BMC, research is always in progress.

Learn more biomedcentral.com/submissions 